\title{
Mineralization Patterns of Maize Straw in Fluvio-Aquatic Soil as Determined by Isotopic Traces
}

\author{
Lixia Zhu ${ }^{1}$, Jutian Chen ${ }^{1}$, Lili Li ${ }^{1, *}$, Fuli Zhang ${ }^{1}$ and Tianxue Liu ${ }^{2, *}$ \\ 1 College of Life Science and Agronomy, Zhoukou Normal University, Zhoukou 466001, China; \\ 20181006@zknu.edu.cn (L.Z.); 20182023@zknu.edu.cn (J.C.); 20101040@zknu.edu.cn (F.Z.) \\ 2 National Key Laboratory of Wheat and Maize Crop Science, Agricultural College of Henan Agricultural \\ University, Zhengzhou 450002, China \\ * Correspondence: 19961011@zknu.edu.cn (L.L.); liutianxue@henau.edu.cn (T.L.)
}

Received: 18 December 2019; Accepted: 13 January 2020; Published: 15 January 2020

check for updates

\begin{abstract}
The mineralization of plant residues results in changes in soil $\mathrm{C}$ and $\mathrm{N}$. However, it is difficult to determine the origins of $\mathrm{C}$ and $\mathrm{N}$ from either soil organic matter mineralization or residue decomposition using traditional methods. An incubation experiment containing two treatments (blank soil (BS) and soil with 6\% maize straw (MS)) was conducted to assess the contributions of maize straw to gas emissions, and to soil organic carbon (SOC) and total nitrogen (TN) using isotopic tracers. About $11.5 \%$ of maize straw $C$ was sequestered in soil, the cumulative amount of $C$ emitted from MS was 2.5-fold higher than that in BS treatment. A positive priming effect of maize straw on native SOC in the first 14 days was observed, and then became negative, indicating the potential for a positive balance of SOC storage. Cumulative $\mathrm{N}_{2} \mathrm{O}$ emissions in MS markedly decreased by $22.4 \%$ compared with BS, and the loss of $\mathrm{N}$ via $\mathrm{N}_{2} \mathrm{O}$ in $\mathrm{MS}$ was approximately $3.3 \%$. Maize straw significantly increased soil TN and contributed $15.8 \%$ to TN at day 120 . Our study clearly demonstrated that the different dynamics of ${ }^{13} \mathrm{C}$ and ${ }^{15} \mathrm{~N}$ in the soils and gases indicated differences of maize straw $\mathrm{C}$ and $\mathrm{N}$ during decomposition. Maize straw $\mathrm{C}$ preferred to contribute to $\mathrm{CO}_{2}$ emissions, while maize straw $\mathrm{N}$ contributed more to soil TN.
\end{abstract}

Keywords: $\mathrm{CO}_{2}$ emissions; isotopic signature; $\mathrm{N}_{2} \mathrm{O}$ emissions; priming effect; soil organic matter

\section{Introduction}

Soil organic matter (SOM) consists of heterogeneous pools with different stability and turnover rates, and plays a vital role in maintaining soil fertility; SOM is a source of nutrients of soil as well [1]. The equilibrium between the formation and decomposition of SOM determines the level of the organic matter pool [2]. In the past, crop residues were often removed and burned, resulting in losses of SOM from the system. Returning crop residues to the soil is being accepted, as it maintains the soil organic carbon (SOC) content and improves soil fertility and microbial activity [3]. During the decomposition of crop residues, $\mathrm{CO}_{2}$ is emitted, and nutrients essential to crop growth are released [4]. The application of straw could delay $\mathrm{N}$ release, increase the crop yield, and reduce $\mathrm{N}$ losses from the soil-plant system [5]. The addition of organic materials to agricultural soil is important for replenishing the annual $\mathrm{C}$ losses, and for improving both the biological and chemical properties of soil. Therefore, understanding the dynamics of plant-soil-atmosphere processes is critical for predicting the cycles of global C and N.

Stable isotopes are widely used in assessing plant $\mathrm{C}$ and $\mathrm{N}$ assimilation [6] and rhizodeposition [7], because isotope ration of residue can be distinguished with soil isotopes [8]. Litter decomposition [9], soil organic matter formation [10], soil gas emissions [9], and soil C residence time [11] have also been evaluated via stable isotopes, based on their natural abundance or their artificial label. 
When $C 4$ plant residues are incorporated into soil that was previously planted with $\mathrm{C} 3$ vegetation, the SOM contains both $\mathrm{C}$ sources, and the values of soil $\delta^{13} \mathrm{C}$ changes [12]. However, no change in ${ }^{13} \mathrm{C}$ discrimination during soil respiration has been widely reported [13]. Thus, additional research on isotopic fractionation in ${ }^{13} \mathrm{C}$ during the decomposition of organic matter in soil is required. When crop residues are added to the soil, the newly added $C$ from the crop residues affects the native SOM through a priming effect [14]. Negative, positive, or even neutral priming effects could occur, depending on the organic substrates $[15,16]$. Most studies have considered priming effects as taking place for hours to several days during the early stage of decomposition $[15,16]$. However, the priming effect is not a short-term response, and may last for weeks or months [14]. The decomposition of crop residue usually is divided into three stages, namely, rapid, intermediate, and slow decomposition [17]. Thus, the priming effects of crop residues need to be evaluated in the latter stage of decomposition, as they might differ from those in the early stage.

Nitrogen is a limiting nutrient for soil processes, representing an important entity, not only in the $\mathrm{N}$ cycle, but also in $\mathrm{C}$ sequestration in soils [18]. The signature of ${ }^{15} \mathrm{~N}$ was also used to differentiate between the intrinsic and newly-added $\mathrm{N}$ following the soil changes [19]. Plant residue- $\mathrm{N}$ is a vital source of $\mathrm{N}$ in stable SOM, and Bird et al. [20] showed heterogeneous pathways of residue-C and residue-N during the formation of SOM. Therefore, plant residues labeled with ${ }^{15} \mathrm{~N}$ were useful in addressing the degradation of SOM, available soil $\mathrm{N}$ and SOM-N pools [21]. When studying the recovery of $\mathrm{N}$ mineralization from ${ }^{15} \mathrm{~N}$-labeled residues over three years under field conditions, the recovery of residue $\mathrm{N}$ decreased from $4.5 \%$ to $1.1 \%$ over the long-term [22]. However, elevated $\mathrm{CO}_{2}$ resulted in an $18 \%$ higher recovery of residue $\mathrm{N}$ [23].

Based on our knowledge, the simultaneous fates and transformations of residue-C and residue- $\mathrm{N}$ during plant residue decomposition are far from being fully understood [24]. Therefore, we conducted a 120-day incubation experiment, where we applied ${ }^{15} \mathrm{~N}$-labeled maize straw. The objectives of this study were to investigate (1) the direct contribution of maize residues to soil C and N, and (2) the effects of maize straw addition on the dynamics of soil native organic $C$, which is indicated as priming effect. We hypothesize that there is a difference between residue- $\mathrm{C}$ and residue- $\mathrm{N}$, and that maize straw decomposition will affect the native SOC.

\section{Materials and Methods}

\subsection{Soil and Maize Straw}

The soil was collected from a site with mature evergreen trees in Zhoukou, Henan Province $\left(33^{\circ} 38^{\prime} \mathrm{N}, 114^{\circ} 40^{\prime} \mathrm{E}\right)$ in 2018 . The soil samples were passed through a 2-mm sieve to remove the plant material and large aggregates, then air-dried in the shade. The $\mathrm{pH}\left(1: 2.5\right.$ soil: $\left.\mathrm{H}_{2} \mathrm{O}\right)$ was 7.55 , and the concentrations of SOC and total N (TN) were $21.46 \mathrm{~g} \mathrm{~kg}^{-1}$ and $2.15 \mathrm{~g} \mathrm{~kg}^{-1}$, respectively. The values of soil $\delta^{13} \mathrm{C}$ and ${ }^{15} \delta \mathrm{N}$ were $-20.38 \%$ ond $4.85 \%$, respectively.

The maize straw used in this experiment was labeled with ${ }^{15} \mathrm{~N}$ and was prepared based on a previous field experiment. The maize straw contained $411.91 \mathrm{~g} \mathrm{~kg}^{-1} \mathrm{C}$ with a $\delta^{13} \mathrm{C}$ value of $-12.42 \%$ o and $7.24 \mathrm{~g} \mathrm{~kg}^{-1} \mathrm{~N}$ with a $\delta^{15} \mathrm{~N}$ value of $1562.63 \%$, and it had a C:N ratio of 56.89 and a $\mathrm{pH}$ value of 6.72 .

\subsection{Incubation Experiment}

The incubation experiment was conducted over a four-month period, and consisted of the following two treatments: BS (blank soil) and MS (soil and 6\% maize straw (g straw $100 \mathrm{~g}^{-1}$ soil)). Jars with $100 \mathrm{~g}$ soil were pre-incubated with distilled water to a $40 \%$ water holding capacity (WHC). Then, the 1-L jars were incubated at $25^{\circ} \mathrm{C}$ in the dark for seven days to stabilize the microbial activity. Half of the pre-incubated soils were noted as having BS treatment, and maize straw was homogeneously mixed into the reminder of the soils at a rate of $6 \%$, which was noted as MS the treatment. Of the two sets of jars, with each jar being prepared in quintuplicate, one set of soil was used for the gas sampling and the second set was used for soil organic $\mathrm{C}$ and $\mathrm{N}$ sampling. To minimize water loss, the jars were 
sealed with Parafilm which was removed only 20 min before sampling. During the incubation, the soil water content was adjusted to $60 \%$ WHC by weighting and adding distilled water every two days. All of the jars were placed in a controlled environment incubator at $25^{\circ} \mathrm{C}$ in a random block design.

\subsection{Measurement of Gas Emissions and Soil C and N}

The headspace air was sampled on days $1,2,3,4,5,6,7,10,14,18,22,28,38,64,80,100$, and 120 using a gas tight syringe. Each jar was sealed with an airtight butyl stopper perforated by centered Perspex tubes, and was vacuumed and flushed with fresh air using a multiport vacuum manifold. An additional $20 \mathrm{~mL}$ of fresh air was then immediately injected into the jars using a plastic syringe, and was evenly mixed with headspace gas, and the same volume gas was sampled as the zero-time samples for analysis. The jars were returned to the incubator and another $20 \mathrm{~mL}$ of headspace gas in the jars was sampled after $1 \mathrm{~h}$ of enclosure. The concentrations of $\mathrm{N}_{2} \mathrm{O}$ and $\mathrm{CO}_{2}$ were simultaneously analyzed using a gas chromatograph (Agilent 7890A, Shanghai, China) equipped with an electron capture detector (ECD) for the $\mathrm{N}_{2} \mathrm{O}$ analysis, and a hydrogen flame ionization detector (FID) for the $\mathrm{CO}_{2}$ analysis. The gas standards were supplied by the National Research Center for Certified Reference Material, Beijing, China. The values of $\delta^{13} \mathrm{C}$ in the emitted $\mathrm{CO}_{2}$ and the values of $\delta^{15} \mathrm{~N}$ in the emitted $\mathrm{N}_{2} \mathrm{O}$ were measured by the Institute of Soil Science of the Chinese Academy of Sciences.

The samples in each treatment from the incubation experiment were removed at 1, 7, 14, 28, 80, and 120 days of incubation to measure the SOC and TN. The SOC was measured with $\mathrm{K}_{2} \mathrm{Cr}_{2} \mathrm{O}_{7}-\mathrm{H}_{2} \mathrm{SO}_{4}$ oxidation [25], and the TN concentration was analyzed using the Kjeldahl digestion procedure [26]. The stable isotope compositions of ${ }^{13} \delta \mathrm{C}$ and ${ }^{15} \delta \mathrm{N}$ were determined using an isotope mass spectrometer (MAT-253, Thermo Fisher, Waltham, MA, USA).

\subsection{Calculations}

The amount of total $\mathrm{C}$ mineralized was calculated by the linear interpolation of two neighboring measured rates, and numerical integration over time. The $\mathrm{C}$ mineralization was fitted to the first-order kinetic function, as follows:

$$
\mathrm{C}_{\mathrm{m}}=\mathrm{C}_{\mathrm{p}} \times\left(1-\mathrm{e}^{-\mathrm{K} \times \mathrm{t}}\right)
$$

where $C_{m}$ is the cumulative value of mineralized $C\left(\mathrm{mg} \mathrm{g}^{-1}\right)$ during time $t ; C_{p}$ is the potentially mineralizable $C\left(\mathrm{mg} \mathrm{g}^{-1}\right)$, which mainly comprised of labile organic $C$; $K$ is the decay rate constant $\left(\mathrm{d}^{-1}\right)$; and $\mathrm{t}$ is the time of incubation $(\mathrm{d})$ characterized by the potential mineralizable $\mathrm{C}$ in soil. The half residence time of the organic $C$ decomposition was calculated by $\mathrm{T}_{1 / 2}=\ln 2 / \mathrm{K}$.

In this study, we assumed that the $\delta^{13} \mathrm{C}\left(\delta^{15} \mathrm{~N}\right)$ values of $\mathrm{CO}_{2}\left(\mathrm{~N}_{2} \mathrm{O}\right)$ and $\mathrm{SOC}(\mathrm{TN})$ that originated from maize straw were equal to the $\delta^{13} \mathrm{C}\left(\delta^{15} \mathrm{~N}\right)$ value of maize straw, and the $\delta^{13} \mathrm{C}\left(\delta^{15} \mathrm{~N}\right)$ values of $\mathrm{CO}_{2}\left(\mathrm{~N}_{2} \mathrm{O}\right)$ and SOC (TN) that originated from the soil without maize straw were equal to the $\delta^{13} \mathrm{C}$ $\left(\delta^{15} \mathrm{~N}\right)$ values of the native soil [27]. Large differences in the $\delta^{13} \mathrm{C}$ and $\delta^{15} \mathrm{~N}$ values of maize straw and native soil would enable us to differentiate between the sources of the gas emissions and soils, based on the isotope values.

The values of $\delta^{13} \mathrm{C}$ and $\delta^{15} \mathrm{~N}$ were expressed as follows:

$$
\delta(\%)=\left(R_{\text {sample }}-R_{\text {standard }}\right) \times 1000 / R_{\text {standard }}
$$

where $R_{\text {sample }}$ and $R_{\text {standard }}$ are the ${ }^{13} \mathrm{C} /{ }^{12} \mathrm{C}$ or ${ }^{15} \mathrm{~N} /{ }^{14} \mathrm{~N}$ ratios of the sample and standard, respectively [28]. The $\delta^{13} \mathrm{C}$ values are recorded relative to the Vienna Pee Dee Belemnite standard $\left({ }^{13} \mathrm{C} /{ }^{12} \mathrm{C}=(11237.2 \pm 90) \times 10^{-6}\right)$, and the values of $\delta^{15} \mathrm{~N}$ are reported relative to atmospheric $\mathrm{N}$ $\left({ }^{15} \mathrm{~N} /{ }^{14} \mathrm{~N}=3.6765 \times 10^{-3}\right)$.

The proportion of $\mathrm{C}$ or $\mathrm{N}$ derived from the maize straw was calculated using the following calculation:

$$
f(\%)=(\delta-\delta s) /(\delta r-\delta s) \times 100 \%
$$


where $f(\%)$ is the proportion of $C$ or $\mathrm{N}$ derived from the maize straw, $\delta$ is the $\delta^{13} \mathrm{C}$ or $\delta^{15} \mathrm{~N}$ value of the soil with maize straw during incubation, $\delta s$ is the $\delta^{13} \mathrm{C}$ or $\delta^{15} \mathrm{~N}$ value of the initial soil, and $\delta r$ is the initial $\delta^{13} \mathrm{C}$ or $\delta^{15} \mathrm{~N}$ value of the maize straw [28].

The concentration of $\mathrm{C}$ or $\mathrm{N}$ from maize straw $(\mathrm{X})$ was calculated as follows:

$$
X\left(\mathrm{~g} \mathrm{~kg}^{-1}\right)=f \times \rho
$$

where $\rho$ is concentration of the SOC or TN.

It was possible to determine the amount of native soil organic matter subjected to priming after the addition of maize straw. The priming effect of maize straw on native SOC during incubation was calculated with the following formula:

$$
\mathrm{PE}(\%)=\left(\mathrm{CO}_{2 \text {-straw }}-\mathrm{CO}_{2 \text {-soil }}\right) / \mathrm{CO}_{2 \text {-soil }} \times 100 \%
$$

where $\mathrm{CO}_{2 \text {-straw }}$ is the amount of $\mathrm{CO}_{2}$ derived from the native SOC in the soil with maize straw (MS treatment), and $\mathrm{CO}_{2 \text {-soil }}$ is the amount of $\mathrm{CO}_{2}$ derived from the $\mathrm{SOC}$ in the $\mathrm{BS}$ treatment. The cumulative priming effect was calculated as the sum of the priming effects in each of the time intervals during incubation in the treatment added with maize straw.

\subsection{Statistical Analysis}

All of the data are expressed on a dry weight basis. All of the variables were tested for homogeneity of variance and normality of distribution prior to analysis, and all of the data met the assumption of the parametric analyses. All of the statistical analyses were carried out using SPSS 19.0 (SPSS Inc., Chicago, USA), where one-way analysis of variance (ANOVA) was used to assess the statistical significance in the values of $\delta^{13} \mathrm{C}$ and $\delta^{15} \mathrm{~N}$ in both treatments over the incubation time, following post-hoc least significant difference (LSD) tests. A paired t-test was carried out to assess the significant differences among the $\mathrm{C}$ mineralization parameters between the two treatments. In all cases, $p<0.05$ was considered as significant. The figures were accomplished with SigmaPlot 12.0 (Systat Software Inc., London, UK).

\section{Results}

\subsection{Carbon and Nitrogen Losses in $\mathrm{CO}_{2}$ and $\mathrm{N}_{2} \mathrm{O}$}

The $\mathrm{CO}_{2}$ emissions rate was relatively low and constant, except for the initial three days in the BS treatment (Figure 1a). During the incubation period, the $\mathrm{CO}_{2}$ emissions rate in the MS treatment decreased rapidly, and reduced to only $5.80 \mathrm{mg} \mathrm{kg}^{-1} \mathrm{~h}^{-1}$ at day 120 , which was $7.33 \%$ of the initial rate. The average emissions rates of $\mathrm{CO}_{2}$ in the $\mathrm{BS}$ and $\mathrm{MS}$ treatments during incubation were $1.76 \mathrm{mg} \mathrm{kg}^{-1} \mathrm{~h}^{-1}$ and $6.19 \mathrm{mg} \mathrm{kg}^{-1} \mathrm{~h}^{-1}$, respectively. The cumulative loss of $\mathrm{CO}_{2}$ was significantly higher in the MS treatment at $17813.18 \mathrm{mg} \mathrm{C} \mathrm{kg}^{-1}$ soil, which was approximately 2.5 times more than that of the BS treatment (Figure 1b).

In contrast to the dynamics of the $\mathrm{CO}_{2}$ emissions, the $\mathrm{N}_{2} \mathrm{O}$ emission rates were not significantly different in the two treatments, ranging from $0.01 \mu \mathrm{g} \mathrm{kg}^{-1} \mathrm{~h}^{-1}$ to $0.37 \mu \mathrm{g} \mathrm{kg}{ }^{-1} \mathrm{~h}^{-1}$ (Figure 1c). A two-phase pattern of soil $\mathrm{N}_{2} \mathrm{O}$ was observed in both treatments. The first phase was observed from day 1 to day 14 , when the $\mathrm{N}_{2} \mathrm{O}$ emissions rate decreased from $0.37 \mu \mathrm{g} \mathrm{kg}^{-1} \mathrm{~h}^{-1}$ to $0.04 \mu \mathrm{g} \mathrm{kg}^{-1} \mathrm{~h}^{-1}$ in the BS treatment, and from $0.23 \mu \mathrm{g} \mathrm{kg}^{-1} \mathrm{~h}^{-1}$ to $0.02 \mu \mathrm{g} \mathrm{kg}^{-1} \mathrm{~h}^{-1}$ in the MS treatment. The second peak of the $\mathrm{N}_{2} \mathrm{O}$ emissions rate reached $0.31 \mu \mathrm{g} \mathrm{kg}^{-1} \mathrm{~h}^{-1}$ at day 22 in the BS treatment, and $0.19 \mu \mathrm{g} \mathrm{kg}^{-1} \mathrm{~h}^{-1}$ at day 18 in the MS treatment. Both emissions rates of $\mathrm{N}_{2} \mathrm{O}$ in the two treatments decreased to $0.01 \mu \mathrm{g} \mathrm{kg}^{-1} \mathrm{~h}^{-1}$ at day 120 . The amount of cumulative $\mathrm{N}_{2} \mathrm{O}$ emissions in the MS treatment was $84.14 \mu \mathrm{g} \mathrm{N} \mathrm{kg}^{-1}$, approximately $77.57 \%$ of that in the BS treatment (Figure $1 \mathrm{~d}, p<0.05$ ). In the end, the MS treatment lost approximately $3.26 \%$ of $\mathrm{N}$ via $\mathrm{N}_{2} \mathrm{O}$ emissions across the incubation. 
The kinetic parameters of $C$ mineralization are reported in Table 1. There was no significant difference between the actual $C$ mineralization $\left(C_{m}\right)$ and potential $C\left(C_{p}\right)$ for both treatments. The potential mineralized $C$ were $1.388 \mathrm{mg} \mathrm{g}^{-1}$ and $4.664 \mathrm{mg} \mathrm{g}^{-1}$ in the BS and MS treatments, respectively. The MS treatment caused a decomposition rate constant $\mathrm{K}$ value of 0.050 , which was significantly higher than that of the BS treatment; the half residence time of organic C decomposition $\left(\mathrm{T}_{1 / 2}\right)$ in the MS treatment was therefore significantly lower than that in the BS treatment (13.86 d in MS treatment vs. $20.39 \mathrm{~d}$ in BS treatment).
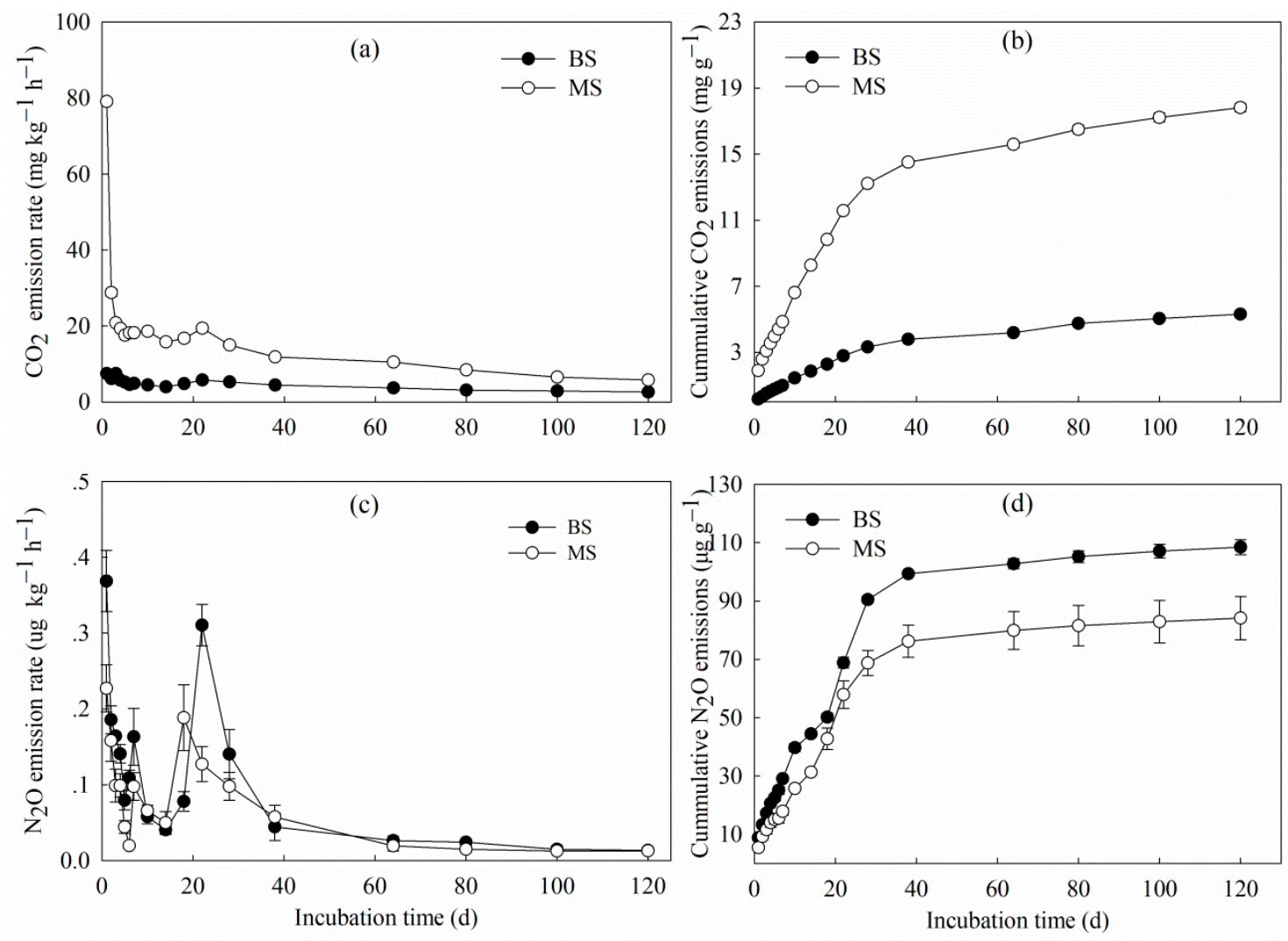

Figure 1. (a) The $\mathrm{CO}_{2}$ emissions rates, (b) cumulative $\mathrm{CO}_{2}$ evolution, (c) $\mathrm{N}_{2} \mathrm{O}$ emission rates, and (d) cumulative $\mathrm{N}_{2} \mathrm{O}$ emissions from soil amended with or without maize straw during incubation. BS—blank soil; MS—soil amended with $6 \%$ maize straw. Values represent means \pm standard deviation $(\mathrm{n}=5)$.

Table 1. The potential cumulative $C$ mineralization in soil amended with or without maize straw after the 120-day incubation. BS—blank soil; MS—-soil amended with $6 \%$ maize straw. Values represent means \pm standard deviations $(n=5)$, different letters within a column indicate significant difference at $p<0.05$.

\begin{tabular}{cccccc}
\hline Treatment & $\mathbf{C}_{\mathbf{m}}\left(\mathbf{m g ~ g}^{\mathbf{- 1}}\right)$ & $\mathbf{C}_{\mathbf{p}}\left(\mathbf{m g ~ g}^{-\mathbf{1}}\right)$ & $\mathbf{K}\left(\mathbf{d}^{\mathbf{- 1}}\right)$ & $\mathbf{T}_{\mathbf{1 / 2}} \mathbf{( d )}$ & $\mathbf{R}^{\mathbf{2}}$ \\
\hline BS & $1.385 \pm 0.008^{\mathrm{b}}$ & $1.388 \pm 0.012^{\mathrm{b}}$ & $0.034 \pm 0.001^{\mathrm{b}}$ & $20.39^{\mathrm{b}}$ & 0.99 \\
MS & $4.858 \pm 0.071^{\mathrm{a}}$ & $4.664 \pm 0.047^{\mathrm{a}}$ & $0.050 \pm 0.001^{\mathrm{a}}$ & $13.86^{\mathrm{a}}$ & 0.99 \\
\hline
\end{tabular}

\subsection{Isotopic Characteristics of $\mathrm{CO}_{2}$ and $\mathrm{N}_{2} \mathrm{O}$}

Throughout the incubation period, the contributions of maize straw $\mathrm{C}$ to the total $\mathrm{CO}_{2}$ emissions were above $65 \%$. The values of $\delta^{13} \mathrm{C}-\mathrm{CO}_{2}$ tended to decrease over the incubation period, and slightly higher $\delta^{13} \mathrm{C}$ values of $\mathrm{CO}_{2}$ were observed in the MS treatment at all sampling times (Table 2). The values of $\delta^{13} \mathrm{C}_{-} \mathrm{CO}_{2}$ in the BS treatment did not change significantly across the incubation. In contrast, the values of $\delta^{13} \mathrm{C}_{-}-\mathrm{CO}_{2}$ in the MS treatment decreased significantly across the incubation and reached $-14.81 \%$ o at 
day 120 . With the highest value on day 1 , the contribution of maize straw $\mathrm{C}$ to $\mathrm{CO}_{2}$ emissions generally decreased with incubation time.

Table 2. Dynamics of $\delta^{13} \mathrm{C}-\mathrm{CO}_{2}$ and $\delta^{15} \mathrm{~N}-\mathrm{N}_{2} \mathrm{O}$ during incubation in $\mathrm{BS}$ and $\mathrm{MS}$ treatments, and changes of proportions of $\mathrm{CO}_{2}\left(f \mathrm{CO}_{2}\right)$ and $\mathrm{N}_{2} \mathrm{O}\left(f \mathrm{~N}_{2} \mathrm{O}\right)$ derived from maize straw in MS treatment. BS—blank soil; MS - soil amended with $6 \%$ maize straw. Values represent means \pm standard deviations $(\mathrm{n}=5)$, different letters within a column indicate significant difference at $p<0.05$, according to least significant difference (LSD) test.

\begin{tabular}{|c|c|c|c|c|c|c|}
\hline \multirow{2}{*}{$\begin{array}{l}\text { Incubation } \\
\text { Time (day) }\end{array}$} & \multicolumn{2}{|c|}{$\delta^{13} \mathrm{C}-\mathrm{CO}_{2}(\%$ o $)$} & \multirow{2}{*}{$f \mathrm{Co}_{2}(\%)$} & \multicolumn{2}{|c|}{$\delta^{15} \mathrm{~N}-\mathrm{N}_{2} \mathrm{O}(\% \mathrm{o})$} & \multirow{2}{*}{$f \mathrm{~N}_{2} \mathrm{O}(\%)$} \\
\hline & BS & MS & & BS & MS & \\
\hline 1 & $-17.84 \pm 0.02^{a}$ & $-13.91 \pm 0.04^{\mathrm{a}}$ & $81.24 \pm 0.52^{\mathrm{a}}$ & $2.03 \pm 0.21^{a}$ & $5.48 \pm 0.01^{b}$ & $0.041 \pm 0.001^{\mathrm{b}}$ \\
\hline 7 & $-18.38 \pm 0.04^{a}$ & $-14.70 \pm 0.19^{b}$ & $71.40 \pm 2.33^{b}$ & $1.90 \pm 0.10^{a}$ & $5.42 \pm 0.04^{b}$ & $0.037 \pm 0.003^{b}$ \\
\hline 14 & $-18.57 \pm 0.07^{\mathrm{a}}$ & $-14.63 \pm 0.05^{b}$ & $72.22 \pm 0.65^{b}$ & $1.88 \pm 0.06^{\mathrm{a}}$ & $5.38 \pm 0.02^{b}$ & $0.034 \pm 0.001^{b}$ \\
\hline 28 & $-18.26 \pm 0.04^{\mathrm{a}}$ & $-15.08 \pm 0.01^{c}$ & $66.55 \pm 0.05^{c}$ & $1.90 \pm 0.03^{\mathrm{a}}$ & $5.53 \pm 0.02^{b}$ & $0.044 \pm 0.002^{b}$ \\
\hline 80 & $-18.21 \pm 0.02^{a}$ & $-14.71 \pm 0.01^{b}$ & $71.20 \pm 0.01^{b}$ & $1.98 \pm 0.07^{\mathrm{a}}$ & $5.81 \pm 0.07 \mathrm{ab}$ & $0.062 \pm 0.005^{\mathrm{ab}}$ \\
\hline 120 & $-18.91 \pm 0.85^{a}$ & $-14.81 \pm 0.07^{b}$ & $69.96 \pm 0.83^{b}$ & $1.85 \pm 0.04^{\mathrm{a}}$ & $6.05 \pm 0.49^{\mathrm{a}}$ & $0.078 \pm 0.032^{a}$ \\
\hline
\end{tabular}

According to the signature of $\delta^{13} \mathrm{C}-\mathrm{CO}_{2}$, the priming effect of maize straw on native soil $\mathrm{C}$ mineralization was calculated. The dynamic of the priming effect fit the model of $y=-23.92+323.83 / x$ $-209.64 / x^{2}$ well (Figure 2). A positive priming effect was observed during the first 14 days, and the highest priming effect $(\mathrm{PE})$ was on day $1(\mathrm{PE}=90.49 \%)$, but the priming effect changed to negative, and tended to decrease with incubation time. The priming effect of maize straw on soil native $\mathrm{C}$ reached $-29.69 \%$ at day 120 . In the end, the cumulative priming effect of maize straw on native SOC was $52.73 \%$ across incubation.

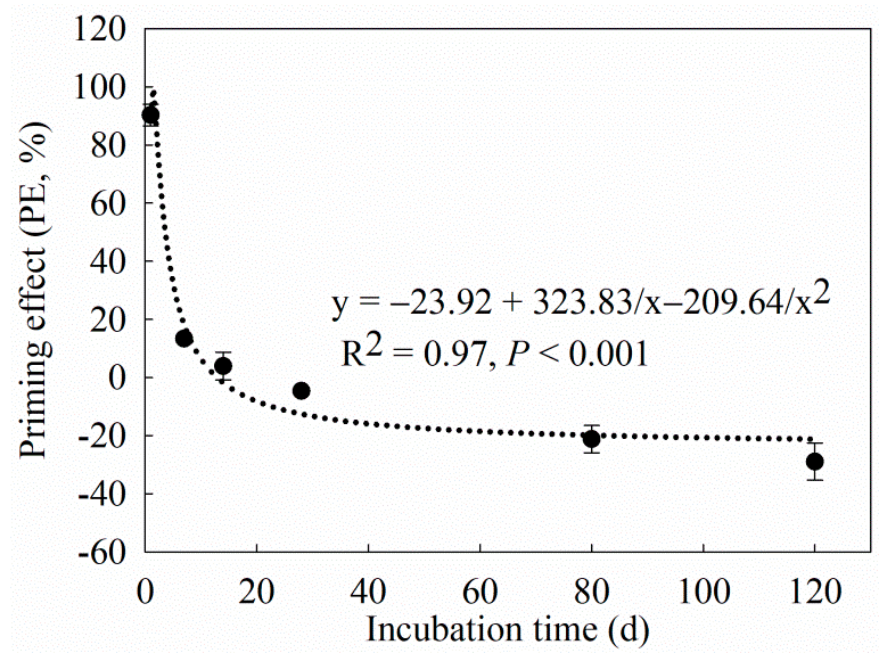

Figure 2. The priming effect of maize straw on soil native organic matter during incubation.

The values of $\delta^{15} \mathrm{~N}-\mathrm{N}_{2} \mathrm{O}$ in the BS treatment were relatively constant, and ranged from $1.85 \%$ o to $2.03 \%$ o (Table 2). Significantly higher than that in the BS treatment, the values of $\delta^{15} \mathrm{~N}-\mathrm{N}_{2} \mathrm{O}$ in the MS treatment increased with time, ranging from $5.38 \%$ o to $6.05 \%$. As shown in Table 2, the contributions of maize straw to $\mathrm{N}_{2} \mathrm{O}$ were all below $0.1 \%$. Like the trend of $\delta{ }^{15} \mathrm{~N}-\mathrm{N}_{2} \mathrm{O}$, the highest contribution of maize straw to $\mathrm{N}_{2} \mathrm{O}$ was observed at day 120 .

\subsection{Changes in $\delta^{13} C-S O C$ and $\delta^{15} N-T N$ During Incubation}

While it was relatively stable in the BS treatment, the SOC showed a slight decrease in MS treatment across the incubation (Figure 3a). The SOC significantly increased in the MS treatment, ranging from $25.65 \mathrm{~g} \mathrm{~kg}^{-1}$ to $27.49 \mathrm{~g} \mathrm{~kg}^{-1}$, compared with the BS treatment (ranging from $21.08 \mathrm{~g} \mathrm{~kg}^{-1}$ to $21.52 \mathrm{~g} \mathrm{~kg}^{-1}$ ), and the SOC was still $21.70 \%$ higher in the MS treatment than that in the BS treatment at 
day 120. The TN in the BS treatment remained relatively stable, ranging from $2.12 \mathrm{~g} \mathrm{~kg}^{-1}$ to $2.24 \mathrm{~g} \mathrm{~kg}^{-1}$ (Figure $3 \mathrm{~b}$ ). In contrast, the TN in the MS treatment significantly increased compared with the BS treatment, and it increased with the incubation time. The soil TN in the MS treatment was $2.54 \mathrm{~g} \mathrm{~kg}^{-1}$ at day 120 , which was $14.93 \%$ higher than that of the BS treatment.
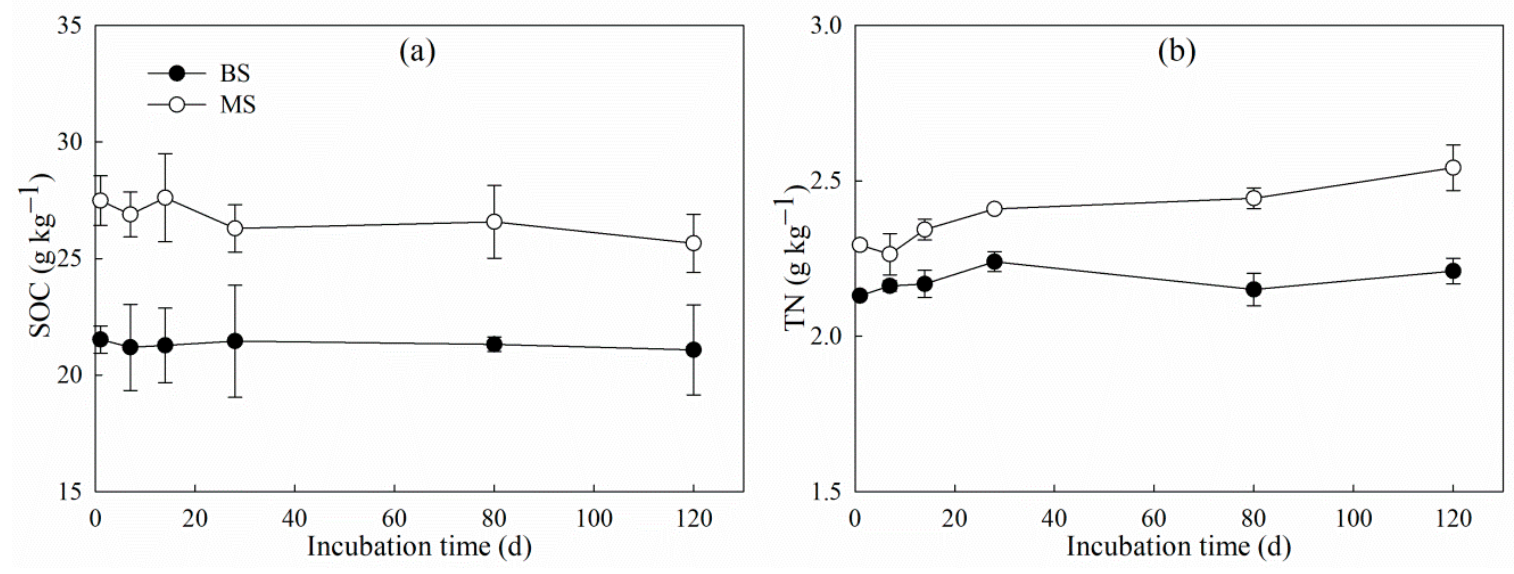

Figure 3. Dynamics of (a) soil organic carbon (SOC) and (b) total nitrogen (TN) in both treatments during the incubation. BS-blank soil; MS—soil amended with $6 \%$ maize straw. Values represent means \pm standard deviation $(n=5)$.

The values of the initial soil $\delta^{13} \mathrm{C}$ and $\delta^{15} \mathrm{~N}$ were $-20.38 \%$ ond $4.85 \%$, respectively. Although the maize straw significantly increased the soil $\delta^{13} \mathrm{C}$ and $\delta^{15} \mathrm{~N}$ during the incubation, the $\delta^{13} \mathrm{C}$ values of the MS treatment showed a small decrease with the incubation time, while $\delta^{15} \mathrm{~N}$ showed a large increase (Table 3). The proportions of organic carbon $\left(f_{O C}\right)$ and nitrogen $\left(f_{N}\right)$ derived from the maize straw also had different trends during the incubation. Decreasing with time, the $f_{O C}$ ranged from $29.67 \%$ at day 1 to $11.45 \%$ at day 120 . After the 120 -day incubation period, only $11.45 \%$ of the total organic soil C was derived from the maize straw. Generally, $f_{N}$ increased with the incubation time, and it ranged from $9.97 \%$ to $15.75 \%$. The maize straw-derived $C$ decreased with the incubation time, while the maize straw-derived $\mathrm{N}$ increased with the incubation time. At the end of incubation, only $3.66 \mathrm{~g} \mathrm{~kg}^{-1} \mathrm{C}$ and $0.40 \mathrm{~g} \mathrm{~kg}^{-1} \mathrm{~N}$ were derived from the maize straw.

Table 3. Dynamics of soil $\delta^{13} \mathrm{C}$, the proportion $\left(f_{\mathrm{OC}}\right)$ and concentration $\left(\mathrm{X}_{\mathrm{OC}}\right)$ of organic carbon derived from maize straw in MS treatment, changes of soil $\delta^{15} \mathrm{~N}$, and the proportion $\left(f_{\mathrm{N}}\right)$ and concentration $\left(\mathrm{X}_{\mathrm{N}}\right)$ of nitrogen derived from maize straw in MS treatment. Values are means of five replicates.

\begin{tabular}{ccccccc}
\hline $\begin{array}{c}\text { Incubation } \\
\text { Time (day) }\end{array}$ & $\boldsymbol{\delta}^{\mathbf{1 3}} \mathbf{C}(\mathbf{\% o})$ & $f_{\mathbf{O C}}(\mathbf{\%})$ & $\mathbf{X}_{\mathbf{O C}}\left(\mathbf{g ~ k g}^{-\mathbf{1}}\right)$ & $\boldsymbol{\delta}^{\mathbf{1 5}} \mathbf{N}(\mathbf{\% o})$ & $f_{\mathbf{N}}(\mathbf{\%})$ & $\mathbf{X}_{\mathbf{N}}\left(\mathbf{g ~ k g}^{-\mathbf{1}}\right)$ \\
\hline 1 & -18.02 & 29.67 & 10.43 & 159.13 & 10.01 & 0.23 \\
7 & -18.54 & 23.17 & 7.94 & 158.60 & 9.97 & 0.23 \\
14 & -18.65 & 21.70 & 7.67 & 170.44 & 10.74 & 0.26 \\
28 & -18.70 & 21.09 & 7.34 & 177.81 & 11.22 & 0.27 \\
80 & -19.29 & 13.98 & 4.81 & 209.78 & 13.04 & 0.32 \\
120 & -19.47 & 11.45 & 3.66 & 248.07 & 15.75 & 0.40 \\
\hline
\end{tabular}

\section{Discussion}

\subsection{Effect of Maize Straw on C Mineralization}

The large differences in the values of $\delta^{13} \mathrm{C}(7.96 \%$ ) between the initial soil and maize straw successfully differentiated the origins of native SOC and maize straw $\mathrm{C}$. In our study, $11.45 \%$ of maize-derived C occurred in the total SOC after the 120-day incubation period, which is lower than the results of Dungait et al. [29], who observed that $60 \%$ of cow dung-C appeared in the soil after 56 days 
of application in a temperate grassland. This variety may be attributed to characteristics of the organic material, for example, dung generally provided more soluble $\mathrm{C}$ and $\mathrm{N}$ compounds for microorganisms, which in turn increased the decomposition of organic $\mathrm{C}$. The C:N ratio of the organic material also affects the decomposition processes [30]. The higher C:N ratio of 56.89 in our study would result in a lower mineralization of maize straw. The difference in the conditions of the lab incubation and field experiments might also contribute to the different results in the studies.

The values of $\delta^{13} \mathrm{C}_{-} \mathrm{CO}_{2}$ in the MS treatment tended to decrease throughout the incubation, suggesting a marked discrimination of the isotope during the decomposition of organic matter. The $\mathrm{CO}_{2}$ that evolved throughout the decomposition of maize straw remained depleted in ${ }^{13} \mathrm{C}$, and the $\delta^{13} \mathrm{C}-\mathrm{CO}_{2}$ was approximately $2 \%$ lower than that in the initial maize straw. This is consistent with the result of Kristiansen et al. [31], who reported that the $\delta^{13} \mathrm{C}-\mathrm{CO}_{2}$ of maize residue incubated with soil or sand was about 3\%o lower than the maize substrate, reiterating that there was significant isotopic fractionation in the decomposition of simple substrates. The $\mathrm{CO}_{2}$ emissions from soil with maize straw were stable in the latter stage of incubation, but $\delta^{13} \mathrm{C}_{-}-\mathrm{CO}_{2}$ generally decreased in our study, suggesting an increased contribution of soil-derived $\mathrm{CO}_{2}$ to the total $\mathrm{CO}_{2}$ emissions. However, the values of $\delta^{13} \mathrm{C}_{-} \mathrm{CO}_{2}$ in the soil with maize straw were higher than that without maize straw in our study, consistent with results of Kristiansen et al. [31], who reported that the $\delta^{13} \mathrm{C}$ values of $\mathrm{CO}_{2}$ evolved from $\mathrm{C}_{3}$ soil and sand were approximately $10 \%$ o higher than in the reference soil, indicating the incorporation and microbial turnover of maize straw into soil. The values of $\delta^{13} \mathrm{C}-\mathrm{CO}_{2}$ in the MS treatment were slightly higher than those of $\delta^{13} \mathrm{C}-\mathrm{SOC}$, which might suggest a cumulative effect of decomposition processes, especially the selective preservation of straw components in soil organic matter [32]. The decrease in $\delta^{13} \mathrm{C}-\mathrm{CO}_{2}$ was positively correlated with that of $\delta^{13} \mathrm{C}-\mathrm{SOC}(\mathrm{r}=0.64, p<0.05)$ during incubation, which might suggest the selective effect of microorganisms on the substrates [33]. A more recalcitrant lignin fraction is ${ }^{13} \mathrm{C}$-depleted compared with cellulose [34]. Changes in the relative abundance of different chemical compounds can therefore lead to shifts in the values of the $\delta^{13} \mathrm{C}$ of decomposing litter. With higher values of $\delta^{13} \mathrm{C}$, the easily decomposable components (such as carbohydrates, cellulose, and water-soluble components) were first degraded at the beginning of incubation; moreover, in the latter stage of incubation, the contents of lignin with lower values of $\delta^{13} \mathrm{C}$ increased, resulting in a decrease in values of soil $\delta^{13} \mathrm{C}$ [34]. Microbial $\mathrm{C}$ usually had high values of $\delta^{13} \mathrm{C}$ [35], and increased proportions of microbial C over time would thus result in an increase in $\delta^{13} \mathrm{C}[36]$. The decomposition of organic residues might be related to the discrimination of ${ }^{13} \mathrm{C}$, resulting in a depletion of ${ }^{13} \mathrm{C}$ in $\mathrm{CO}_{2}$ and an enrichment of $\delta^{13} \mathrm{C}$ in microorganisms [31].

Our results showed a higher contribution of maize straw $\mathrm{C}$ (newly $\mathrm{C}$ ) to $\mathrm{CO}_{2}$ across the incubation, whereas maize straw $\mathrm{C}$ had a much lower influence on SOC. This was consistent with previous studies. Pausch and Kuzyakov [37] reported that less than $5 \%$ of the new $C$ accounted for the total $C$, but the $\mathrm{CO}_{2}$ ranged from $16 \%$ to $50 \%$ in a vegetation changed from $\mathrm{C}_{3}$ to $\mathrm{C}_{4} \mathrm{crop}$. The results of Flessa et al. [38] also showed that maize derived C only contributed $15 \%$ to the SOC, while the contribution to $\mathrm{CO}_{2}$ was $58 \%$, although the maize had been cultivated for 37 years. Therefore, the native soil $\mathrm{C}$ was still prominent in SOC, while the newly added C contributed more to $\mathrm{CO}_{2}$ emissions, reflecting the relative availability of native and newly incorporated $\mathrm{C}$ pools. The maize straw decomposed quickly in the first month, and then the decomposition rate decreased progressively for the remaining time.

Approximately $70 \%$ of maize straw $\mathrm{C}$ was decomposed throughout the incubation, consistent with results of Trinsoutrot et al. [39], who showed that the cumulative mineralization of residue-C was $65 \%-70 \%$ in a field experiment. The soil $C$ decomposition would be primed when the organic materials were applied into soil. The priming effect on the soil organic matter generally not only related to the characteristics of organic materials, but also to the microbial competition of different substrates in soil [40]. Previous studies showed that the priming effect of organic materials on native SOC decomposition changed from $95.1 \%$ inhibition to $1207 \%$ stimulation [41]. A positive priming effect was usually attributed to stimulated microbial growth and the corresponding enzyme activity, while the toxicity of substrates to the microbes might be an explanation for a negative effect $[40,42]$. 
Our results showed that the decomposition of native SOC strongly increased following maize straw incorporation in the first 14 days of incubation, and decreased thereafter. This was consistent with results of Qiu et al. [14], who found that the decomposition of native SOC accelerated from day 7 to day 65 during incubation, and strongly reduced during the remaining incubation time, which corresponded well to the soil mineral $\mathrm{N}$ content. The shift of the priming effect along with the incubation might be due to a decrease in easily decomposable substrates [42]. Previous studies often observed the priming effect in one direction after the amendment of organic materials, which might be attributed to the sampling frequency and properties of organic materials. For example, Zhang et al. [43] observed an increase in SOM decomposition due to the addition of glucose during a 31-day incubation, while a negative priming effect of biochar was recorded for the soil cultivated with $\mathrm{C}_{3}$ crops for more than 50 years [44]. Generally, the decomposition of organic material could be divided into three stages, namely: rapid decomposition of easily decomposable components at the beginning of decomposition, relatively moderate decomposition of cellulose, and low rates of decomposition of lignin at the end of decomposition [17]. In the early stage of incubation, soil species that can grow and reproduce rapidly would use the easily decomposable compounds, thus stimulating microbial growth and activity, which might contribute to a positive priming effect [42]. In addition, large amounts of $C$ applied to soil caused a relative depletion in $\mathrm{N}$, and the disequilibrium of $\mathrm{C}$ and $\mathrm{N}$ aggravated the decomposition of native soil $\mathrm{C}$, resulting in a positive priming effect. The negative priming effect might be due to a release of compounds in maize straw that were absorbed or protected by the soil. Microbes contain a lower $\mathrm{C}: \mathrm{N}$ ratio than soil and crop residues; thus, microbes would prefer to use dead microbial residues in soil [40], and the mineralization of dead microbes also contributed to the negative priming effect.

The concentrations of SOC significantly increased after the addition of maize straw, and a higher $\mathrm{CO}_{2}$ emission was observed in the MS treatment. Approximately $70 \%$ of the maize straw $\mathrm{C}$ was decomposed during the incubation, with an effective accumulated temperature of $3000{ }^{\circ} \mathrm{C}$, which was generally equivalent to the effective accumulated temperature of a growing season for crops. It might be practical for maize straw amendment in soil management to increase SOM. Notably, the negative priming effect of maize straw on native SOC tended to increase with time. However, the duration of the negative priming effect during the latter stage of decomposition remains unknown. Thus, a long-term study is needed to ascertain the underlying mechanism of maize straw decomposition.

\subsection{Effect of Maize Straw on N Loss}

In the present study, maize straw significantly reduced approximately $30 \%$ of the $\mathrm{N}_{2} \mathrm{O}$ emissions. The decreased $\mathrm{N}_{2} \mathrm{O}$ emissions in the MS treatment were consistent with results of Wang et al. [45]. The cumulative $\mathrm{N}_{2} \mathrm{O}$ emissions were generally negatively correlated with the $\mathrm{C}: \mathrm{N}$ ratios of organic materials [46], which were responsible for the equilibrium of $\mathrm{N}$ mineralization and immobilization. Studies have shown that the threshold value of the C:N ratio was 40 [47]. Therefore, the high C:N ratio in the maize straw (56.89) in our study, which was above the threshold, might contribute to lower cumulative $\mathrm{N}_{2} \mathrm{O}$ emissions in the soil with maize straw. The high $\mathrm{C}: \mathrm{N}$ in the maize straw would tie up soil-available $\mathrm{N}$ and sequester $\mathrm{N}$ in the soil [48]. Additionally, a significantly lower $\mathrm{NO}_{3}{ }^{-}$content and higher microbial biomass nitrogen in the soil with maize straw in our previous study [49] may also result in lower $\mathrm{N}_{2} \mathrm{O}$ emissions. The application of maize straw could also provide more readily soluble $C$ to stimulate the final reduction of $\mathrm{N}_{2} \mathrm{O}$ to $\mathrm{N}_{2}$ by denitrification. The emissions rate of $\mathrm{N}_{2} \mathrm{O}$ decreased over time, and could presumably be attributed to the loss of easily decomposable compounds and to increases in recalcitrant components such as lignin, which would reduce the $\mathrm{N}$ availability [50]. Maize straw would generally rot when incorporated into soil, and it consumed a substantial quantity of oxygen, resulting in more severe soil anoxic conditions. $\mathrm{N}_{2} \mathrm{O}$ would be used as an electron acceptor by soil microorganisms, resulting in a reduction in $\mathrm{N}_{2} \mathrm{O}$ emissions under severe soil anoxic conditions [51]. Interestingly, the $\mathrm{N}_{2} \mathrm{O}$ emission rates at about day 20 reached a little peak in both treatments. This peak in BS treatment might be attribute to a loss of soil C, which resulted in an increase in soil mineral $\mathrm{N}$, affecting the nitrification of activities, and therefore the production of $\mathrm{N}_{2} \mathrm{O}$ [52]. The cellulose in maize 
straw was readily accessible for soil microbes [53], and the decomposition of cellulose stimulated the biological activities related to nitrification. However, the inherent mechanism required further research.

In contrast to the signature of soil $\delta^{13} \mathrm{C}$, values of soil $\delta^{15} \mathrm{~N}$ increased over time and reached $248.07 \%$ o in the MS treatment after the 120-day incubation, indicating an increasing incorporation of maize-derived $\mathrm{N}$ into soil over time. The disparity of soil $\delta^{13} \mathrm{C}$ and $\delta^{15} \mathrm{~N}$ might suggest differences in the decomposition of maize straw $\mathrm{C}$ and maize straw N. Consistent with Pérez et al. [54], the values of $\delta^{15} \mathrm{~N}-\mathrm{N}_{2} \mathrm{O}$ increased over time, and reached $6.05 \%$ o at day 120 of the incubation. The high $\delta^{15} \mathrm{~N}$ of maize straw for $\mathrm{N}_{2} \mathrm{O}$ production might contribute to increase in $\delta^{15} \mathrm{~N}-\mathrm{N}_{2} \mathrm{O}$. A strong reduction of $\mathrm{N}_{2} \mathrm{O}$ to $\mathrm{N}_{2}$ by denitrifiers might also be an explanation for the high $\delta^{15} \mathrm{~N}-\mathrm{N}_{2} \mathrm{O}$ [55]. No loss of maize straw $\mathrm{N}$ was recorded from the MS treatment, showing that $\mathrm{N}$ was being recycled within the system. It has been shown that more $\mathrm{C}$ than $\mathrm{N}$ would be lost from the soil during the decomposition of organic matter, because more $\mathrm{N}$ would participate in the internal $\mathrm{N}$ cycle, while $\mathrm{C}$ would be progressively be lost from the soil in the form of $\mathrm{CO}_{2}$ [56]. Additionally, the $\mathrm{TN}$ in soil with maize straw significantly increased compared with that in blank soil. This might be attributed to $\mathrm{N}$ fixation under restricted oxygen conditions [57], large amounts of soluble degradation products accumulated when oxygen was deficient, Azotobacter and Clostridia would be activated and fixed the nitrogen [58]. The amendment of maize straw would be helpful for improving soil $\mathrm{N}$ and decreasing $\mathrm{N}$ loss as a gas.

The dynamics of soil $\delta^{13} \mathrm{C}$ have been widely used to discriminate between native and newly added $\mathrm{C}$ in the field or in an incubation experiment. The application of $\delta^{15} \mathrm{~N}$ in determining original and new formed $\mathrm{N}$, however, has received little attention [19]. The signature and changes of $\delta^{15} \mathrm{~N}$ in soil TN and $\mathrm{N}_{2} \mathrm{O}$ emissions in our study reiterated that measuring $\delta^{15} \mathrm{~N}$ was an informative method to track the transformations of soil N. In this study, we did not determine the isotope dynamics of soil labile $\mathrm{C}$ and $\mathrm{N}$ fractions, which renewed rapidly and reflected the soil quality timely, and whether the contribution of maize straw to $\mathrm{N}_{2} \mathrm{O}$ would increase over time remains unknown. Additionally, soil water and temperature were different between the lab incubation and field experiment. Therefore, further studies on the isotopic characteristics during maize straw decomposition in the lab or under field conditions are required.

\section{Conclusions}

After the 120-day incubation, approximately $65 \%$ of $C$ was lost via $\mathrm{CO}_{2}$ in the soil with maize straw, and the $\mathrm{C}$ turnover rate significantly increased, suggesting that the renewal of SOM was promoted by maize straw. The cumulative $\mathrm{CO}_{2}$ emissions and $\mathrm{SOC}$ were significantly increased by maize straw, and the priming effect of maize straw on soil $\mathrm{C}$ changed from positive to negative across the incubation, indicating the potential of $\mathrm{C}$ sequestration after maize straw amendment. Cumulative $\mathrm{N}_{2} \mathrm{O}$ emissions were significantly decreased by $22.43 \%$ in the soil with maize straw relative to the blank soil, and $3.26 \%$ of $\mathrm{N}$ was lost via $\mathrm{N}_{2} \mathrm{O}$ emissions. In the end, $15.75 \%$ of maize straw $\mathrm{N}$ was incorporated to soil $\mathrm{N}$, and the soil TN was significantly increased by the maize straw. The different dynamics of the stable $\mathrm{C}$ and $\mathrm{N}$ isotope signatures in the soil with maize straw across the incubation period indicated differences in the decomposition of maize straw $\mathrm{C}$ and N. Maize straw $\mathrm{C}$ contributed to $\mathrm{CO}_{2}$ emissions, while maize straw $\mathrm{N}$ contributed more to soil $\mathrm{TN}$ more $\mathrm{N}_{2} \mathrm{O}$ emissions. As maize straw was progressively incorporated into soil $\mathrm{C}$ and $\mathrm{N}$, as indicated by the decreased $\delta^{13} \mathrm{C}$ and increased $\delta^{15} \mathrm{~N}$, maize straw addition was an effective practice for $\mathrm{C}$ and $\mathrm{N}$ sequestration in soil. These results confirmed the importance of ${ }^{13} \mathrm{C}$ and ${ }^{15} \mathrm{~N}$ discrimination in assessing the dynamics of carbon and nitrogen in soil systems.

Author Contributions: This paper was written by L.Z. in collaboration with all of the co-authors. The data were collected by J.C. The first and final drafts were written by L.Z. The results were analyzed by L.Z. and J.C. The major revisions of this paper were completed by L.Z., L.L., and F.Z. This paper was financially sponsored by T.L. All authors have read and agreed to the published version of the manuscript. 
Funding: This research was funded by the National Key Research and Development Program of China, grant number 2018YFD0300704; the Foundation of He'nan Educational Committee, grant number 20B21002, and the School-Based Project of Zhoukou Normal University, grant number ZKNUC2018012.

Conflicts of Interest: The authors declare no conflict of interest.

\section{References}

1. Desjardins, T.; Folgarait, P.J.; Pando-Bahuon, A.; Girardin, C.; Lavelle, P. Soil organic matter dynamics along a rice chronosequence in north-eastern Argentina: Evidence from natural ${ }^{13} \mathrm{C}$ abundance and particle size fractionation. Soil Biol. Biochem. 2006, 38, 2753-2761. [CrossRef]

2. Laudicina, V.A.; Badalucco, L.; Palazzolo, E. Effects of compost input and tillage intensity on soil microbial biomass and activity under Mediterranean conditions. Biol. Fertil. Soils 2011, 47, 63-70. [CrossRef]

3. Cayuela, M.L.; Sinicco, T.; Mondini, C. Mineralization dynamics and biochemical properties during initial decomposition of plant and animal residues in soil. Appl. Soil Ecol. 2009, 41, 118-127. [CrossRef]

4. Vinther, F.P.; Hansen, E.M.; Olesen, J.E. Effects of plant residues on crop performance, N mineralisation and microbial activity including field $\mathrm{CO}_{2}$ and $\mathrm{N}_{2} \mathrm{O}$ fluxes in unfertilised crop rotations. Nutr. Cycl. Agroecosyst. 2004, 70, 189-199. [CrossRef]

5. Kaewpradit, W.; Toomsan, B.; Cadisch, G.; Vityakon, P.; Limpinuntana, V.; Saenjan, P.; Jogloy, S.; Patanothai, A. Mixing groundnut residues and rice straw to improve rice yield and $\mathrm{N}$ use efficiency. Field Crops Res. 2009, 110, 130-138. [CrossRef]

6. Andresen, L.C.; Jonasson, S.; Ström, L.; Michelsen, A. Uptake of pulse injected nitrogen by soil microbes and mycorrhizal and non-mycorrhizal plants in a species-diverse subarctic heath ecosystem. Plant Soil 2008, 313, 283-295. [CrossRef]

7. Denef, K.; Bubenheim, H.; Lenhart, K.; Vermeulen, J.; Cleemput, O.V.; Boeckx, P.; Müller, C. Community shifts and carbon translocation within metabolically-active rhizosphere microorganisms in grasslands under elevated $\mathrm{CO}_{2}$. Biogeosci. Discuss. 2007, 4, 769-779. [CrossRef]

8. Zhu, B.; Cheng, W. ${ }^{13} \mathrm{C}$ isotope fractionation during rhizosphere respiration of $\mathrm{C} 3$ and C4 plants. Plant Soil 2011, 342, 277-287. [CrossRef]

9. Rubino, M.; Dungait, J.A.J.; Evershed, R.P.; Bertolini, T.; Angelis, P.D.; D'Onofrio, A.; Lagomarsino, A.; Lubritto, C.; Merola, A.; Terrasi, F. Carbon input belowground is the major C flux contributing to leaf litter mass loss: Evidences from a ${ }^{13} \mathrm{C}$ labelled-leaf litter experiment. Soil Biol. Biochem. 2010, 42, 1009-1016. [CrossRef]

10. Mambelli, S.; Bird, J.A.; Gleixner, G.; Dawson, T.E.; Torn, M.S. Relative contribution of foliar and fine root pine litter to the molecular composition of soil organic matter after in situ degradation. Organ. Geochem. 2011, 42, 1099-1108. [CrossRef]

11. Blagodatskaya, E.; Blagodatsky, S.; Kuzyakov, Y.; Yuyukina, T. Turnover of soil organic matter and of microbial biomass under $\mathrm{C} 3-\mathrm{C} 4$ vegetation change: Consideration of ${ }^{13} \mathrm{C}$ fractionation and preferential substrate utilization. Soil Biol. Biochem. 2011, 43, 159-166. [CrossRef]

12. Werth, M.; Kuzyakov, Y. Root-derived carbon in soil respiration and microbial biomass determined by ${ }^{14} \mathrm{C}$ and ${ }^{13}$ C. Soil Biol. Biochem. 2008, 40, 625-637. [CrossRef]

13. Ekblad, A.; Nyberg, G.; Högberg, P. ${ }^{13}$ C-discrimination during microbial respiration of added $\mathrm{C}_{3^{-}}, \mathrm{C}_{4^{-}}$and ${ }^{13}$ C-labelled sugars to a $C_{3}$-forest soil. Oecologia 2002, 131, 245-249. [CrossRef] [PubMed]

14. Qiu, Q.; Wu, L.; Ouyang, Z.; Li, B.; Xu, Y.; Wu, S.; Gregorich, E.G. Priming effect of maize residue and urea N on soil organic matter changes with time. Appl. Soil Ecol. 2016, 100, 65-74. [CrossRef]

15. Li, L.; Han, X.; You, M.; Yuan, Y.; Ding, X.; Qiao, Y. Carbon and nitrogen mineralization patterns of two contrasting crop residues in a Mollisol: Effects of residue type and placement in soils. Eur. J. Soil Biol. 2013, 54, 1-6. [CrossRef]

16. Chen, R.; Senbayram, M.; Blagodatsky, S.; Myachina, O.; Dittert, K.; Lin, X.; Blagodatskaya, E.; Kuzyakov, Y. Soil $\mathrm{C}$ and $\mathrm{N}$ availability determine the priming effect: Microbial $\mathrm{N}$ mining and stoichiometric decomposition theories. Glob. Chang. Biol. 2014, 20, 2356-2367. [CrossRef]

17. Hadas, A.; Kautsky, L.; Goek, M.; Kara, E.E. Rates of decomposition of plant residues and available nitrogen in soil, related to residue composition through simulation of carbon and nitrogen turnover. Soil Biol. Biochem. 2004, 36, 255-266. [CrossRef] 
18. López-Martín, M.; Nowak, K.M.; Milter, A.; Knicker, H. Incorporation of N from burnt and unburnt ${ }^{15} \mathrm{~N}$ grass residues into the peptidic fraction of fire affected and unaffected soils. J. Soils Sediments 2017, 17, 1-11. [CrossRef]

19. Wei, X.; Huang, L.; Xiang, Y.; Shao, M.; Zhang, X.; Gale, W. The dynamics of soil OC and N after conversion of forest to cropland. Agric. For. Meteorol. 2014, 194, 188-196. [CrossRef]

20. Bird, J.A.; Kessel, C.V.; Horwath, W.R. Stabilization of C-carbon and immobilization of N-nitrogen from rice straw in humic fractions. Soil Sci. Soc. Am. J. 2003, 67, 806-816. [CrossRef]

21. Ismaili, K.; Ismaili, M.; Ibijbijen, J. The use of ${ }^{13} \mathrm{C}$ and ${ }^{15} \mathrm{~N}$ based isotopic techniques for assessing soil $\mathrm{C}$ and $\mathrm{N}$ changes under conservation agriculture. Eur. J. Agron. 2015, 64, 1-7. [CrossRef]

22. Thomsen, I.K.; Jensen, E.S. Recovery of nitrogen by spring barley following incorporation of ${ }^{15} \mathrm{~N}$-labelled straw and catch crop material. Agric. Ecosyst. Environ. 1994, 49, 115-122. [CrossRef]

23. Butterly, C.R.; Wang, X.; Armstrong, R.D.; Chen, D.; Tang, C. Elevated $\mathrm{CO}_{2}$ induced rhizosphere effects on the decomposition and $\mathrm{N}$ recovery from crop residues. Plant Soil 2016, 408, 1-7. [CrossRef]

24. Moran, K. Role of mineral-nitrogen in residue decomposition and stable soil organic matter formation. Soil Sci. Soc. Am. J. 2005, 69, 1730-1736. [CrossRef]

25. Mebius, L.J. A rapid method for the determination of organic carbon in soil. Anal. Chim. Acta 1960, 22, 120-124. [CrossRef]

26. Bremner, J.M.; Tabatabai, M.A. Use of an ammonia electrode for determination of ammonium in Kjeldahl analysis of soils. Commun. Soil Sci. Plant Anal. 1972, 3, 159-165. [CrossRef]

27. Zhang, W.L.; Wang, S.L. Effects of $\mathrm{NH}_{4}{ }^{+}$and $\mathrm{NO}_{3}{ }^{-}$on litter and soil organic carbon decomposition in a Chinese fir plantation forest in South China. Soil Biol. Biochem. 2012, 47, 116-122. [CrossRef]

28. Liang, B.C.; Gregorich, E.G.; MacKenzie, A.F. Short-term mineralization of maize residues in soils as determined by carbon-13 natural abundance. Plant Soil 1999, 208, 227-232. [CrossRef]

29. Dungait, J.A.J.; Bol, R.; Bull, I.D.; Evershed, R.P. Tracking the fate of dung-derived carbohydrates in a temperate grassland soil using compound-specific stable isotope analysis. Organ. Geochem. 2009, 40, 1210-1218. [CrossRef]

30. Li, L.J.; Zeng, D.H.; Yu, Z.Y.; Fan, Z.P.; Yang, D.; Liu, Y.X. Impact of litter quality and soil nutrient availability on leaf decomposition rate in a semi-arid grassland of Northeast China. J. Arid Environ. 2011, 75, 787-792. [CrossRef]

31. Kristiansen, S.M.; Brandt, M.; Hansen, E.M.; Magid, J.; Christensen, B.T. ${ }^{13} \mathrm{C}$ signature of $\mathrm{CO}_{2}$ evolved from incubated maize residues and maize-derived sheep faeces. Soil Biol. Biochem. 2004, 36, 99-105. [CrossRef]

32. Henn, M.R.; Chapela, I.H. Differential C isotope discrimination by fungi during decomposition of C3- and C4-derived sucrose. Appl. Environ. Microbiol. 2000, 66, 4180-4186. [CrossRef] [PubMed]

33. Ngao, J.; Cotrufo, M.F. Carbon isotope discrimination during litter decomposition can be explained by selective use of substrate with differing $\delta^{13} \mathrm{C}$. Biogeosci. Discuss. 2011, 8, 51-82. [CrossRef]

34. Yang, W.J.; Bruun, S.; Rønn, R.; Ekelund, F.; Magid, J. Turnover and isotopic fractionation of carbon from maize leaves as influenced by clay type and content in constructed soil media. Biol. Fertil. Soils 2016, 52, 447-454. [CrossRef]

35. Coyle, J.S.; Dijkstra, P.; Doucett, R.R.; Schwartz, E.; Hart, S.C.; Hungate, B.A. Relationships between C and $\mathrm{N}$ availability, substrate age, and natural abundance ${ }^{13} \mathrm{C}$ and ${ }^{15} \mathrm{~N}$ signatures of soil microbial biomass in a semiarid climate. Soil Biol. Biochem. 2009, 41, 1605-1611. [CrossRef]

36. Wedin, D.A.; Tieszen, L.L.; Dewey, B.; Pastor, J. Carbon isotope dynamics during grass decomposition and soil organic matter formation. Ecology 1995, 76, 1383-1392. [CrossRef]

37. Pausch, J.; Kuzyakov, Y. Soil organic carbon decomposition from recently added and older sources estimated by $\delta^{13} \mathrm{C}$ values of $\mathrm{CO}_{2}$ and organic matter. Soil Biol. Biochem. 2012, 55, 40-47. [CrossRef]

38. Flessa, H.; Ludwig, B.; Heil, B.; Merbach, W. The origin of soil organic C, dissolved organic C and respiration in a long-term maize experiment in Halle, Germany, determined by ${ }^{13} \mathrm{C}$ natural abundance. J. Plant Nutr. Soil Sci. 2000, 163, 157-163. [CrossRef]

39. Trinsoutrot, I.; Nicolardot, B.; Justes, E.; Recous, S. Decomposition in the field of residues of oilseed rape grown at two levels of nitrogen fertilisation. Effects on the dynamics of soil mineral nitrogen between successive crops. Nutr. Cycl. Agroecosyst. 2000, 56, 125-137. [CrossRef]

40. Fontaine, S.; Mariotti, A.; Abbadie, L. The priming effect of organic matter: A question of microbial competition? Soil Biol. Biochem. 2003, 35, 837-843. [CrossRef] 
41. Zhang, W.; Wang, X.; Wang, S. Addition of external organic carbon and native soil organic carbon decomposition: A meta-analysis. PLoS ONE 2013, 8, e54779. [CrossRef] [PubMed]

42. Kuzyakov, Y.; Friedel, J.K.; Stahr, K. Review of mechanisms and quantification of priming effects. Soil Biol. Biochem. 2000, 32, 1485-1498. [CrossRef]

43. Zhang, Y.; Yao, S.; Mao, J.; Olk, D.C.; Cao, X.; Zhang, B. Chemical composition of organic matter in a deep soil changed with a positive priming effect due to glucose addition as investigated by ${ }^{13} \mathrm{C}$ NMR spectroscopy. Soil Biol. Biochem. 2015, 85, 137-144. [CrossRef]

44. Lu, W.; Ding, W.; Zhang, J.; Li, Y.; Luo, J.; Bolan, N.; Xie, Z. Biochar suppressed the decomposition of organic carbon in a cultivated sandy loam soil: A negative priming effect. Soil Biol. Biochem. 2014, 76, 12-21. [CrossRef]

45. Wang, J.Y.; Jia, J.X.; Xiong, Z.Q.; Mak, K.; Xing, G.X. Water regime-nitrogen fertilizer-straw incorporation interaction: Field study on nitrous oxide emissions from a rice agroecosystem in Nanjing, China. Agric. Ecosyst. Environ. 2011, 141, 437-446. [CrossRef]

46. Khalil, M.I.; Rosenani, A.B.; Ovan, C.; Boeckx, P.; Shamshuddin, J.; Fauziah, C.I. Nitrous oxide production from an ultisol of the humid tropics treated with different nitrogen sources and moisture regimes. Biol. Fertil. Soils 2002, 36, 59-65.

47. Toma, Y.; Hatano, R. Effect of crop residue C: $\mathrm{N}$ ratio on $\mathrm{N}_{2} \mathrm{O}$ emissions from Gray Lowland soil in Mikasa, Hokkaido, Japan. Soil Sci. Plant Nutr. 2010, 53, 198-205. [CrossRef]

48. Al-Sheikh, A.; Delgado, J.A.; Barbarick, K.; Sparks, R.; Dillon, M.; Qian, Y.; Cardon, G. Effects of potato-grain rotations on soil erosion, carbon dynamics and properties of rangeland sandy soils. Soil Tillage Res. 2005, 81, 227-238. [CrossRef]

49. Zhu, L.X.; Xiao, Q.; Shen, Y.F.; Li, S.Q. Effects of biochar and maize straw on the short-term carbon and nitrogen dynamics in a cultivated silty loam in China. Environ. Sci. Pollut. Res. 2017, 24, 1019-1029. [CrossRef]

50. Yao, Z.; Zhou, Z.; Zheng, X.; Xie, B.; Mei, B.; Wang, R.; Butterbach-Bahl, K.; Zhu, J. Effects of organic matter incorporation on nitrous oxide emissions from rice-wheat rotation ecosystems in China. Plant Soil 2010, 327, 315-330. [CrossRef]

51. Wrage, N.; Velthof, G.L.; Beusichem, M.L.V.; Oenema, O. Role of nitrifier denitrification in the production of nitrous oxide. Soil Biol. Biochem. 2001, 33, 1723-1732. [CrossRef]

52. Yao, Z.; Zheng, X.; Xie, B.; Mei, B.; Wang, R.; Klaus, B.B.; Zhu, J.; Yin, R. Tillage and crop residue management significantly affects $\mathrm{N}$-trace gas emissions during the non-rice season of a subtropical rice-wheat rotation. Soil Biol. Biochem. 2009, 41, 2131-2140. [CrossRef]

53. Say, E.W.; Dines, A.J. Dissolved organic carbon and nitrogen relationships in forest litter as affected by nitrogen deposition. Soil Biol. Biochem. 2000, 32, 603-613.

54. Pérez, T.; Trumbore, S.E.; Tyler, S.C.; Matson, P.A.; Ortiz-Monasterio, I.; Rahn, T.; Griffith, D.W.T. Identifying the agricultural imprint on the global $\mathrm{N}_{2} \mathrm{O}$ budget using stable isotopes. J. Geophys. Res. Atmos. 2001, 106, 9869-9878. [CrossRef]

55. Xia, Z.; Xu, H.; Chen, G.; Dong, D.; Bai, E.; Luo, L. Soil $\mathrm{N}_{2} \mathrm{O}$ production and the $\delta^{15} \mathrm{~N}-\mathrm{N}_{2} \mathrm{O}$ value: Their relationship with nitrifying/denitrifying bacteria and archaea during a growing season of soybean in northeast China. Eur. J. Soil Biol. 2013, 58, 73-80. [CrossRef]

56. Aita, C.; Recous, S.; Angers, D.A. Short-term kinetics of residual wheat straw $\mathrm{C}$ and $\mathrm{N}$ under field conditions: Characterization by ${ }^{13} \mathrm{C}^{15} \mathrm{~N}$ tracing and soil particle size fractionation. Eur. J. Soil Sci. 1997, 48, 283-294. [CrossRef]

57. Barrow, N.J.; Jenkinson, D.S. The effect of water-logging on fixation of nitrogen by soil incubated with straw. Plant Soil 1962, 16, 258-262. [CrossRef]

58. Katsuki, A.; Iwao, W.; Michiharu, K.; Eiichi, T. Effect of application of glucose, cellulose, and rice straw on nitrogen fixation (acetylene reduction and soil-nitrogen components) in anaerobic soil. Soil Sci. Plant Nutr. $1989,35,235-243$.

(C) 2020 by the authors. Licensee MDPI, Basel, Switzerland. This article is an open access article distributed under the terms and conditions of the Creative Commons Attribution (CC BY) license (http://creativecommons.org/licenses/by/4.0/). 